\title{
Screening for Salt Tolerance in Melons
}

\author{
Samuel Mendlinger and Dov Pasternak \\ Institutes for Applied Research, Ben-Gurion University of Negev, Beer- \\ Sheva 84110, Israel
}

Additional index words. Cucumis melo, genetic variation, fruit weight, fruit count

\begin{abstract}
Twenty melon (Cucumis melo L.) cultigens (cultivars and breeding lines) were tested for salt tolerance. All cultigens were grown in the field using drip irrigation at three salt salinity levels: electrical conductivity $\left(\mathrm{EC}_{\mathrm{w}}=1.2,7.5\right.$, or $14.0 \mathrm{dS} \cdot \mathrm{m}^{-1}$. Nineteen of the 20 cultigens proved to be salt-sensitive, as measured by reduction in fruit weight, but not necessarily to the same degree (i.e., some cultigens were tolerant at $\mathrm{EC}_{\mathrm{w}}=7.5$, whereas others were not). One line, 'Evan Key', was salt-tolerant at $E_{\mathrm{w}}=14.0$. Increasing salinity levels did not affect the number of fruits produced in most cultigens. Overall, increasing salinity reduced netting quality but increased the total soluble solids content and shortened mean time to harvest in seven cultigens.
\end{abstract}

Melon is an important crop in many arid and semiarid regions of the world and is often grown in areas where salinity threatens to become, or already is, a problem (Epstein et al., 1980). Several authors reported that melon displays a moderate though variable tolerance to salinity (Mangal et al., 1988; Meiri et al., 1982, Mohamed and Abdel-Salem, 1972; Nerson and Paris, 1984; Shannon et al., 1984; Shannon and Francois, 1978). In all these studies, however, salt tolerance was examined in relatively few cultivars or in a restricted range of germplasm, or else the

Received for publication 13 May 1991. Accepted for publication 2 Jan. 1992. The cost of publishing this paper was defrayed in part by the payment of page charges. Under postal regulations, this paper therefore must be hereby marked advertisement solely to indicate this fact. plants were grown in a greenhouse under conditions very different from the field. No attempt was made to assess potential variability for salinity tolerance over a wide spectrum of the gene pool in a field study. In our study, 20 melon cultigens consisting of elite cultivars (open-pollinated and hybrids), older cultivars, and landraces were screened for salt tolerance in a field trial

The field trials were conducted at the Ramat HaNegev Field Station, Israel, where the soil is a light, sandy loam. The experiment was designed as a Latin Square with three irrigation salinity treatments: control $\left(\mathrm{EC}_{\mathrm{w}}=1.2 \mathrm{dS} \cdot \mathrm{m}^{-1}\right)$, moderate $\left(\mathrm{EC}_{\mathrm{w}}=\right.$ $\left.7.5 \mathrm{dS} \cdot \mathrm{m}^{-1}\right)$, and high salinity $\left(\mathrm{EC}_{\mathrm{w}}=14.0\right.$ $\left.\mathrm{dS} \cdot \mathrm{m}^{-1}\right)$. Salinity levels were attained by injecting the appropriate amount of a concentrated $\mathrm{NaCl}: \mathrm{CaCl}$ brine solution (molar ratio 3:1) into the control water using a brine in- 
Table 1. Response pattern, number of fruit, mean fruit weight (percentage of control), and mean days to harvest in 20 melon cultivars grown at three salt concentrations.

\begin{tabular}{|c|c|c|c|c|c|c|c|c|c|c|}
\hline \multirow[b]{2}{*}{ Cultigen } & \multirow[b]{2}{*}{ Pattem } & \multicolumn{3}{|c|}{$\begin{array}{l}\text { No. fruit } \\
\text { at } E C_{w}\left(d S_{m^{-1}}\right)\end{array}$} & \multicolumn{3}{|c|}{$\begin{array}{l}\text { Mean fruit wt }(g) \\
\text { at } E C_{w}\left(d S^{-1}\right)\end{array}$} & \multicolumn{3}{|c|}{$\begin{array}{l}\text { Mean days to harvest } \\
\text { at } E C_{w}\left(\mathrm{dS} \cdot \mathrm{m}^{-1}\right)\end{array}$} \\
\hline & & 1.2 & 7.5 & 14 & 1.2 & 7.5 & 14 & 1.2 & 7.5 & 14 \\
\hline Evan Key & $\mathbf{A}$ & 36 & 52 & 53 & 985 & $1029(104)$ & $1180(119)$ & 114 & 114 & 114 \\
\hline Hales Best & B & 74 & 69 & 107 & 899 & $881(98 i$ & $758(84)^{*}$ & 105 & 100 & $101 *$ \\
\hline Topmark & $\mathrm{C}$ & 69 & 53 & $82^{* 1}$ & 927 & $835(90)$ & $829(89)^{*}$ & 108 & 103 & 107 \\
\hline Ein Dor & $\mathrm{C}$ & 55 & 66 & 43 & 1288 & $1067(83)$ & $1056(82)^{* * *}$ & 110 & 104 & $103^{*}$ \\
\hline Ananas & $\mathrm{C}$ & 77 & 62 & 72 & 745 & $608(82)$ & $606(81)^{* *}$ & 107 & 107 & $102^{\circ}$ \\
\hline Sharon & C & 87 & 79 & 95 & 1103 & $963(87)$ & $964(87)^{* *}$ & 101 & 98 & $98^{*}$ \\
\hline Casaba & $\mathrm{C}$ & 41 & 46 & 29 & 2256 & $1812(80)$ & $1917(85)^{* *}$ & 126 & 130 & 126 \\
\hline Earty Hackensack & C & 87 & 56 & $62^{*}$ & 1260 & $1042(84)$ & $966(77)^{* *}$ & 99 & 103 & 101 \\
\hline Galia & D & 89 & 75 & 66 & 1425 & $1146(80)$ & $923(76)^{* *}$ & 99 & 97 & 96 \\
\hline Makdemon & $\mathrm{D}$ & 62 & 74 & 62 & 1274 & $1040(82)$ & $914(71)^{\cdots}$ & 94 & 95 & 93 \\
\hline Noy Amid & $\mathrm{D}$ & 47 & 50 & 45 & 1847 & $1499(84)$ & $1410(76)^{* *}$ & 105 & 108 & 106 \\
\hline Gulfstream & D & 89 & 116 & 95 & 855 & $707(84)$ & $537(63)^{=*}$ & 109 & 102 & $104^{*}$ \\
\hline Perlita & $\mathrm{D}$ & 88 & 120 & $72 * 0$ & 978 & $807(84)$ & $747(76)^{*}$ & 106 & 105 & $99=$ \\
\hline Planters Jumbo & D & 72 & 91 & 80 & 1249 & $1013(81)$ & $893(71)^{*}$ & 107 & 105 & 104 \\
\hline Jaune Canaria & $\vec{D}$ & 44 & 53 & 31 & 1662 & $1415(85)$ & $1219(79)^{\circ}$ & 107 & 108 & 109 \\
\hline Amarelo & D & 55 & 47 & 45 & 1275 & $1163(91)$ & $849(67)^{* 0}$ & 109 & 110 & 109 \\
\hline Crenshaw & $\bar{D}$ & 32 & 30 & 27 & 2781 & $2050(74)$ & $1920(69)^{\circ}$ & 120 & 121 & 120 \\
\hline Persian & D & 48 & 34 & 33 & 1696 & $1587(94)$ & $1486(88)^{* * *}$ & 117 & 115 & 114 \\
\hline Cavaillon & D & 51 & 43 & 40 & 1332 & $1100(83)$ & $991(74)^{* *}$ & 103 & 99 & 101 \\
\hline Earl's Favorite & D & 67 & 76 & 50 & 944 & $768(81)$ & $719(76)^{* *}$ & 115 & 110 & $111^{\circ}$ \\
\hline
\end{tabular}

* Standard deviations were $25 \%$ to $35 \%$ of mean in most cultigens for mean fruit weight and $5 \%$ for mean days to harvest.

$* 0.05>P>0.01 ; * * P<0.01$.

Table 2. Number of fruit and mean fruit weight of four melon cultigens at three salt concentrations. ${ }^{2}$

\begin{tabular}{|c|c|c|c|c|c|c|}
\hline \multirow[b]{2}{*}{ Cultigen } & \multicolumn{3}{|c|}{$\begin{array}{l}\text { Mean no. fruit } \\
\text { at } E C_{w}\left(d S \cdot m^{-1}\right)\end{array}$} & \multicolumn{3}{|c|}{$\begin{array}{l}\text { Mean fruit wt }(g) \\
\text { at } \operatorname{EC}_{w}\left(d S \cdot m^{-1}\right)\end{array}$} \\
\hline & 1.2 & 8 & 15 & 1.2 & 8 & 15 \\
\hline $\begin{array}{l}\text { Evan Key } \\
\text { Noy Amid } \\
\text { Topmark } \\
\text { Gulfstream }\end{array}$ & $\begin{array}{r}95 \\
113 \\
88 \\
104\end{array}$ & $\begin{array}{r}112 \\
88 \\
106 \\
101\end{array}$ & $\begin{array}{r}83 \\
83 \\
76 \\
130\end{array}$ & $\begin{array}{r}964 \mathrm{a} \\
1137 \mathrm{a} \\
775 \mathrm{a} \\
850 \mathrm{a}\end{array}$ & $\begin{array}{r}931 \mathrm{a} \\
1001 \mathrm{~b} \\
720 \mathrm{~b} \\
758 \mathrm{~b}\end{array}$ & $\begin{array}{l}996 \mathrm{a} \\
909 \mathrm{c} \\
722 \mathrm{~b} \\
674 \mathrm{c}\end{array}$ \\
\hline
\end{tabular}

${ }^{\mathrm{z}}$ Mean separation within rows by Fisher's LSD $(P<0.05)$; 18 plants per treatment.

Table 3. Effects of salinity on some quality characteristics of melon fruit at three salinity concentrations $\left(\mathrm{EC}=1.2,7.5\right.$, and $\left.14.0 . \mathrm{dS} \cdot \mathrm{m}^{-1}\right)$.

\begin{tabular}{llll}
\hline \hline & \multicolumn{3}{c}{ EC } \\
\cline { 2 - 4 } Character & \multicolumn{1}{c}{1.2} & \multicolumn{1}{c}{7.5} & 14.0 \\
\hline Netting (\%) & 86 & 84 & 81 \\
TSS & $10.2 \mathrm{~b}$ & $10.6 \mathrm{~b}$ & $11.3 \mathrm{a}$ \\
$\begin{array}{l}\text { Reducing sugars } \\
\quad\left(\mathrm{mgg}^{-1} \mathrm{fw}\right)\end{array}$ & 32.4 & 31.2 & 31.9 \\
$\mathrm{EC}$ & & & \\
$\quad\left(\mathrm{ds} \cdot \mathrm{m}^{-1}\right)$ & 4.47 & 4.31 & 4.59 \\
$\mathrm{pH}$ & 6.17 & 6.09 & 6.17 \\
\hline
\end{tabular}

${ }^{\mathrm{z}}$ Mean separation within tows by Fisher's LSD $(P$ $<0.05)$. Data are means of more than 50 fruits.

jection system coupled with a manifold irrigation head with a single source of water but three outflows, one for each saline treatment (Pasternak et al., 1986). Salinity levels were measured with a portable electrical conductivity meter at every irrigation. Each treatment, replicated three times, consisted of five raised beds, each $30 \mathrm{~m}$ long. The field received a pretreatment of ammonium sulfate $\left(800 \mathrm{~kg} \cdot \mathrm{ha}^{-1}\right)$ and superphosphate $(600$ $\left.\mathrm{kg} \cdot \mathrm{ha}^{-1}\right)$. A single drip line with 2-liter $\mathrm{h}^{-1}$ drippers spaced $1 \mathrm{~m}$ apart was placed down the middle of each bed.

Seeds from each of the 20 cultigens were sown in the greenhouse on 19 May 1983 and transplanted into the field on 15 June when all plants had two to three leaves. In each replicate, seven plants per cultigen were planted $1 \mathrm{~m}$ apart in a row and within $5 \mathrm{~cm}$ of a dripper. The first and seventh plants were border plants and excluded from the analyses. For the first 3 weeks, all treatments received the control water, then, when almost all cultigens had open pistillate flowers, the salinity treatments were initiated.

Harvest began on 16 Aug. and henceforth the entire field was harvested three times per week. Fruits were harvested at full slip when applicable or upon achieving mature coloring. All fruits from each plant were harvested, weighed, and checked for percentage of surface netting. One fruit per plant, usually the third one hatvested, was analyzed for total soluble solids (TSS) content, reducing sugars, $\mathrm{pH}$, and electrical conductivity.

Regression analysis of fruit count and mean fruit weight on salinity level was performed. However, with only three salt treatments, the power of the regression test was found to be poor. Fruit count was analyzed using a $x^{2}$ test and mean fruit weight, mean days to harvest, netting, and fruit constituents were evaluated using analysis of variance.

The following year, using the same protocol as above, but with eight plants instead of seven and seed sown 3 weeks later, 'Evan Key', 'Topmark', 'Noy Amid', and 'Gulfstream' were examined for mean fruit weight and number of fruit produced.

The field was visually examined every 2 weeks. Vegetative growth appeared healthy and more or less vigorous in all cultigens with no apparent diseases. While neither rate of growth nor total vegetative biomass were determined, salinity appeared to reduce vegetative growth in all cultigens.

Overall, salinity did not affect the number of fruit produced (Table 1). In 16 of the 20 cultigens, no statistically significant differences were detected among the three treatments, while the remaining four cultigens exhibited different responses to salinity. The casaba or honeydew types usually had fewer fruit than the netted melons.

The cultigens can be grouped into four patterns (A through D) according to their responses to the affects of salinity on mean fruit weight. In A, plants were salt-tolerant with no mean fruit weight reduction under high salinity ('Evan Key'). The other three patterns all exhibited decline in mean fruit weight under salinity but the pattern of decline varied (Table 1). In $B$, represented by 'Hales Best', mean fruit weight remained unchanged at moderate salinity but declined at high salinity. In $\mathrm{C}$, mean fruit weight was reduced by moderate salinity but higher salinity had no additional effect on weight; included here were 'Sharon', 'Ein Dor', 'Topmark', 'Ananas', 'Casaba', and 'Early Hackensack'. Pattern D, characteristic of the majority of cultigens, had the classic pattern of an almost linear reduction in fruit weight with increasing salinity (Mass and Hoffman, 1977). As there was no statistical difference in the number of fruit per treatment in the different cultigens, total yield paralleled mean fruit weight.

In the majority of cultigens time to harvest was not significantly affected by salinity (Table 1); however, for 'Sharon', 'Ein Dor', 'Hales Best', 'Gulfstream', 'Perlita', 'Ananas', and 'Earl's Favorite', increasing salinity shortened the time to harvest by 2 to 7 days. 
The results of the second-year field study were the same as for the first year for response to increasing salinity in the four cultigens. 'Evan Key' was salt-tolerant, 'Topmark' moderately tolerant, and 'Noy Amid' and 'Gulfstream' salt-sensitive (Table 2). However, in the second year, 'Evan Key', 'Topmark', and 'Noy Amid' had substantially more fruit per plant but smaller fruit than in the first year.

In most of the cultigens examined in the first year, salinity reduced the percentage netting of the fruit and, therefore, its appearance and marketability (Table 3). TSS increased with salinity, although the concentration of reducing sugars did not. The percentage increase in TSS was less than that reported in tomatoes (Lycopersicon esculentum Mill.) (Mizrahi and Pasternak, 1985), but similar to that found previously in melon (Shannon and Francois, 1978). Electrical conductivity and $\mathrm{pH}$ of the fruit were unaffected.

Mean fruit weight was found to be the best selection criterion to determine salt tolerance, with marked differences in salt tolerance among cultigens. Previous studies found a linear reduction in either mean fruit weight or yield for melons with increasing salinity (Mangal et al., 1988; Shannon and Francois, 1978), a trend we observed in most but not all cultigens. Also, the level of salinity tolerance observed in this study was higher in some cultigens than previously reported. For example, 'Topmark' was found to be relatively tolerant under salinity, whereas Shannon and Francois (1978) and Meiri et al. (1982) reported it to be more sensitive. We can offer two explanations for these differences. First, we began the salinity treatments only after initiation of flowering, whereas most others commenced treatments at an earlier stage. Second, we used drip irrigation with the plants transplanted within $5 \mathrm{~cm}$ of a dripper. It has been shown that, with drip irrigations, one receives higher yields for a given water salinity than with other irrigation systems (Pasternak et al., 1986).

\section{Literature Cited}

Epstein, E., J. Norlyn, D. Rush, R. Kingsbury, D. Kelley, G. Cunningham, and A. Wrona. 1980. Saline culture of crops: A genetic approach. Science 210:399404.

Mass, E.V. and G.J. Hoffman. 1977. Crop salt tolerance-A current assessment. J. Irr. Drainage Div. Amer. Soc. Chem. Eng. 103:115-134.

Maneal. J.L.. P.S. Hooda. and S. Lal. 1988. Salt tolerance of five muskmelon cultivars. J. Agr. Sci. 110:641-643.

Meiri, A., G. Hoffman, M.N. Shannon, and J. Poss. 1982. Salt tolerance of two muskmelon cultivars under two solar radiation levels. J. Amer. Soc. Hort. Sci. 107:1168-1172.

Mizrahi, Y. and D. Pastemak 1985. Effect of salinity on quality of various agricultural crops. Plant \& Soil 89:301-307.

Mohamed, S. and Y. Abdel-Salem. .1972. Effect of different salt concentrations on germination and early seedling growth of some vegetables and field crops. Desert Inst. Bul. A.R.E. 22:485496.

Nerson, H. and H.S. Paris. 1984. Effects of salinity on germination, seedling growth and yield in melons. Irr. Sci. 5:265-269.

Pasternak, D., A. Azoulai, A. Danon, S. Levi, Y. DeMalach, and D. Shalev. 1986. Irrigations with brackish water under desert conditions. VI. Automated systems to produce a range of salt concentrations in irrigation water for experimental plots. Agr. Water Mgt. 12:137-147.
Shannon, M., G. Bohn, and J. McCreight. 1984. Salt tolerance among muskmelon genotypes during seed emergence and seedling growth. HortScience 19:828-830.

Shannon, M. and L. Francois. 1978. Salt tolerante of three muskmelon cultivars. J. Amer. Sot. Hort. Sci. 103:127-130.

HortSCIENCE 27(8):907-908. 1992.

\title{
Clip-and-wash Method of Emasculation for Lettuce
}

\author{
R.T. Nagata \\ University of Florida, Institute of Food and Agricultural Sciences, \\ Everglade Research and Education Center, P.O. Box 8003, Belle Glade, \\ FL 33430-8003
}

Additional index words. hybridization, Lactuca sativa, vegetable breeding

Abstract. Complete (100\%) hybridization in lettuce (Lactuca sativa L.) was accomplished consistently using the clip-and-wash method of emasculation. The clip-andwash method is a combination of washing and clipping, two previously described procedures for pollen removal. The wash and the clip methods produced $98 \%$ and $95 \%$ hybridization, respectively. The method is quick and easy and eliminates inadvertent self pollination; with it one can produce the many hybrid seeds necessary for backcross and $F_{1}$ genetic analysis in lettuce.

Genetic studies and cultivar development in lettuce are handicapped by its pollination biology and by breeders' inability to achieve $100 \%$ crosses consistently. Marker genes, such as disease resistance or morphological traits, are commonly used to distinguish hybrids and self-pollinations. The dependence on marker traits inhibits progress in a breeding program and genetic studies, since more seeds must be produced and additional plants grown to compensate for self-pollinated plants. Further, marker genes in specific crosses may be absent, difficult to identify, and/or are expressed only in mature plants, flowers, or seeds. This situation mandates lengthy waiting to determine the number of hybrids produced and increases the number of crosses needed to compensate for the inadvertent self-pollinations.

Lettuce is an obligate self-fertilizing species, which dehisces pollen before stigma emergence (Vavilov, 1935). Hence, hybridization success is determined by the effectiveness of the emasculation/depollination procedure. Oliver (1910) used a thin stream of water to remove pollen and variations of this technique are commonly used today (Ryder, 1986). Manual removal of the anthers with forceps was described by ErnstSchwarzenbach (1932). That procedure proved to be tedious since each capitulum

Received for publication 24 May 1991. Accepted for publication $24 \mathrm{Feb}$. 1992. Univ. of Florida Agr. Expt. Sta., Journal Series no. R-02160. The cost of publishing this paper was defrayed in part by the payment of page charges. Underpostal regulations, this paper therefore must be hereby marked advertisement solely to indicate this fact. was an aggregate of $\approx 10$ to 20 individual florets, each requiring separate emasculation. Pearson (1962) clipped off the corolla tips of the florets in the early morning, removing most of the anther sheath. Ryder and Johnson (1974) used an intermittent fine mist for depollination, which was a modification of the method used by Oliver (1910). Success levels for all methods described ranged from $10 \%$ to $100 \%$. None provided $100 \%$ hybridization consistently. For example, the misting procedure described by Ryder and Johnson (1974) resulted in 57\% of the crosses with $100 \%$ hybridization, $41 \%$ with $80 \%$ to $95 \%$ hybridization, and $2 \%$ with $60 \%$ hybridization. The following report describes a reliable, simple procedure of corolla clipping and pollen washing to achieve $100 \%$ hybrid seed production in lettuce.

About 30 to $60 \mathrm{~min}$ past sunrise, flower buds that will open that day are selected for pollination (Fig. 1A). The corolla and all floret parts contained within the bud are clipped level with the top of the involucre (Fig. 1B). Since emergence rate of the style depends on temperature and light intensity, trial and error may be needed to select the proper clipping time to avoid damaging the style and stigma. The clipped flowers are then washed with a medium fine stream of water from a hand-held misting/spray bottle. The nozzle is held $\approx 1 \mathrm{~cm}$ from the flower. Flowers are sprayed with three to four pumps of water per flower to wash away pollen, latex, and/or flower parts adhering to the bud. The flowers then are inspected about every 15 min with a hand lens for signs of style elongation. At stigma emergence, flowers are washed every 10 to $15 \mathrm{~min}$ for 40 to $75 \mathrm{~min}$ 